Article

\title{
Governing Grazing and Mobility in the Samburu Lowlands, Kenya
}

\author{
Annemiek Pas \\ Department of Human Geography, Stockholm University, Svante Arrhenius väg 8 , \\ Se-106 91 Stockholm, Sweden; annemiek.schrijver@humangeo.su.se; Tel.: +46-700-128-959
}

Received: 11 January 2018; Accepted: 29 March 2018; Published: 31 March 2018

\begin{abstract}
Pastoral mobility is seen as the most effective strategy to make use of constantly shifting resources. However, mobile pastoralism as a highly-valued strategy to manage grazing areas and exploit resource variability is becoming more complex, due to recurrent droughts, loss of forage, government-led settlement schemes, and enclosure of land for community conservation, among other reasons. Yet knowledge of how Samburu pastoralists perceive these changes, and govern and innovate in their mobility patterns and resource use, has received limited attention. This paper seeks to understand how Samburu pastoralists in the drylands of northern Kenya use and govern natural resources, how livestock grazing and mobility is planned for, and how boundaries and territory are constructed and performed both within and beyond the context of (non)governmental projects. Fieldwork for this paper was conducted in Sesia, Samburu East, and consisted of interviews, focus group discussions, and participatory observation. Findings show that livestock mobility involves longer periods and more complex distances due to a shrinking resource base and new rules of access. Although access was previously generated based on the value of reciprocity, the creation of new forms of resource management results in conditional processes of inclusion and exclusion. Policy and project implementation has historically been driven by the imperative to secure land tenure and improve pasture in bounded areas. Opportunities to support institutions that promote mobility have been given insufficient attention.
\end{abstract}

Keywords: communal grazing regulations; pastoral mobility; boundaries; Samburu pastoralists; Kenya

\section{Introduction}

African rangelands, also referred to as drylands or arid and semi-arid lands (ASALs), cover about two-thirds of sub-Saharan Africa [1] and are characterized by unpredictable rainfall and variations in vegetation growth leading to highly dynamic environments [2-4]. In these rangelands, pastoral mobility is seen as the most effective strategy to sustain both pastoralism as a livelihood and rangeland environments [5-7]. In northern Kenya, rangelands are mainly grass-growing savannah ecosystems which constantly co-evolve with mobile livestock herding, predominantly based on cattle, but increasingly also goats, sheep, and camels $[8,9]$. Pastoralists move around with livestock herds in search of water and pasture. Such pastoral mobility is carefully planned in order to make optimal use of the variation of resources in time and space. Rainfall and the ensuing quantity and distribution of grasses are important factors in determining how livestock mobility occurs. In addition to ecological factors, socio-political access to and control over territories are involved in the decision-making process. Hence, pastoralists optimize differing factors-the changing environment, the needs of different resource users, and social, cultural, and political constraints- to access pastures while managing conflict, a process which is supported by flexible and reciprocal social arrangements $[5,6,10,11]$.

However, the context of pastoral mobility in northern Kenya has changed radically over time, not least during the last two decades. Rangeland fragmentation, boundary formation, climate change, 
violent conflict, and rangeland degradation, as well as political marginalization and forced settlement schemes create resources and mobility constraints for pastoralists who are increasingly dependent on livestock mobility [12-19]. Rangeland-enclosing processes are becoming more common [20-24] while farmer-herder conflicts are increasing [25,26]. Additionally, conservation and large-scale infrastructural developments to modernize pastoral areas create significant obstacles for the continuation of mobile pastoralism while adding to the dynamic of further fragmentation, marginalization, and conflict [27-29].

In a growing number of African states, a recent shift in policy and legislation to formally recognize and support pastoral mobility has taken place, particularly in West Africa, but also in Kenya [30,31]. This 'mobility paradigm', importantly, breaks significantly with common views about pastoralists as destroyers of the environment who are responsible for widespread rangeland degradation through overstocking, overgrazing, and overpopulation [32-37]. Former policies aimed to settle pastoralists and to provide support for the improvement of rangelands [7], if there was any policy at all [38].

For Kenya, current policies for the improvement of pastoralist livelihoods in the ASALs mainly focus on the 'stabilization and development' of northern Kenya, where development is not only of benefit to the pastoralists, but also for Kenya as a state. More specifically, in the 'National Policy for the Sustainable Development of Northern Kenya and other Arid Lands', the ASALs are recognized for their specific characteristics regarding mobile livelihoods and hence the need to develop governance and services that target mobile populations [31]. At the same time, in the 'Vision 2030 Development Strategy for Northern Kenya and other Arid Lands', the ASALs are mainly seen for their importance to national policy and planning, in order to make use of their 'untapped potential' concerning trade, tourism, and energy [27]. Furthermore, Vision 2030 promotes the inclusion of pastoralists in national development as a way to curtail the continuous marginalization of pastoral areas and to make the ASALs 'equal to the rest of Kenya' [31,39]. Additionally, the new 2010 Constitution, and the Community Land Act (2016) - where pastoralists' livelihoods are perceived as valuable and in need of formalized and documented rights to their land-all mark a shift in thinking about pastoral land use and promote the use of customary institutions for managing resources and (cross-border) mobility [27,40].

Although pastoral mobility has gained recognition in policy and legislation, it has lacked support in its implementation [6,31], and hardships and struggles to access resources are still part of daily practice in the drylands within the context of rapidly changing socio-economical and climatic conditions shaping and negatively affecting livelihoods of pastoralists $[12,14,41]$. Therefore, it is important to recognize current patterns of constructing livelihoods by pastoralists and draw important lessons from local struggles and opportunities [8,11,42-44].

This paper focuses on the Samburu management of grazing areas, pastoral mobility, and grazing access amid shifting socio-ecological conditions in the lowlands of Samburu County. In Samburu County, pasture availability is decreasing and the need for long-distance pastoral mobility is increasing. To date, however, limited research has been carried out on how Samburu pastoralists move with their livestock within this complex landscape. Research at the intersection of Samburu culture, ecology, and biology was carried out extensively in the 1970s and 1980s [45-48]. Later work comprehensively describes Samburu livelihoods and coping strategies during droughts [49,50], followed by extensive anthropological work on Samburu culture, gender, and sexuality, among other topics [51,52]. Furthermore, significant research on pastoralists in Samburu County has been directed towards pastoralist sedentarization, land privatization, and economic diversification with a strong focus on institutions of resource governance [21,53,54], whereas little research has focused on pastoral mobility [55]. Southern Kenya, on the other hand, has been the subject of a number of studies on pastoral mobility $[5,56,57]$.

The aim of this paper was to examine shifting relations between Samburu pastoralists, the land, and the resources (which are variable over space and time) by looking closely at patterns of mobility and institutions governing resource access in a semi-nomadic setting [58]. To achieve this, I did fieldwork in Samburu, Isiolo, and Laikipia, Kenya, for a total period of 12 months conducting interviews, group 
discussions, and participatory observation. I explored how Samburu pastoralists gain and maintain access to natural resources through grazing management and access negotiations as part of governing mobility and grazing within a shrinking resource base. In addition to an understanding of how current pastoral mobility among Samburu pastoralists is governed using concepts of mobility, access, and institutions, this approach provides a deeper understanding of shifting engagements with space by focusing on new sets of relations that emerge in the processes of gaining and controlling access to resources [15,58-60]. This paper is organized as follows: Section 2 provides theoretical background of the study. In Section 3 I explain the methods used and introduce the research area. In Section 4 I present the results, focusing on shifting access relations and mobility patterns within the study area. The discussion and conclusions ensue in Sections 5 and 6, respectively.

\section{Mobility, Access, and Institutions}

In northern Kenya, pastoral systems are inherently flexible, enabling families and households to make effective use of constantly shifting resources. In this paper, livestock mobility, movement, and migration are used interchangeably to refer to the movement of (segments of) households with livestock, including cattle, goats, sheep, and camels—often with the assistance of donkeys—in search of water and pasture [61]. Mobile pastoralism can be ordered in various forms, from daily circular movements around a homestead, here referred to as short-distance mobility, to large-scale movements, and combinations of these $[6,46]$. The distance and frequency of such movements depend on multiple factors and are highly place-specific. In this paper I draw specific attention to long-distance cattle herding. Such livestock mobility is energy-costly for the livestock, as well as the herders, resulting in a declining ability to move for longer distances as a drought proceeds. At times, herds are split into separate herds to release the pressure on the herder, although this depends, among other things, on the availability of herding labour. Furthermore, in a pastoral society where resources are unpredictable and fluctuating, access consists of social relations constituted across the landscape. Mobility over long distances means that herders need to have a strong and wide social network of connections to share information and to access pastures and water points maintained by other communities [7].

Pastoral mobility, then, is not only an ecological endeavour, but social and relational as well [7,15,62-64]. In order to access these resources, social connections are formed to gain and maintain such access. Access to resources over a communally managed area must be negotiated and is managed according to certain regulations [5]. Here, access to resources is defined as "the ability to benefit from things" [60] (p. 153), mutually and continuously constituted out of processes and relations between people and nature. Within a socio-political landscape, access claims are subject to processes of, and relations to, power and authority, as well as rules and regulations, that, combined, govern access and control over specific resources $[5,59,64,65]$.

Objects of access for (semi)nomadic pastoralists can vary between paths and sites, which can be anywhere within a landscape $[7,62]$. More specifically, tenure rules and regulations exist around water points and specific vegetation as opposed to a grounded surface, or land:

Thus when it turns out [ ... ] that a clan holds a cluster of sites, we do not have to suppose that this follows from their inclusion within a bounded area, which for some strange reason is not recognized by the people themselves. On the contrary, the surrounding country is held by virtue of its inclusion, in some sense, within the sites themselves. Land does not contain sites; rather, the sites contain the land [62] (p. 156)

This distinction between access regulations existing around objects existing and/or growing on the land, and the land itself, is highly relevant for understanding the multiple ways in which access is gained, maintained, and controlled in semi-nomadic pastoral societies where resources are patchily distributed [64,65]. Access and control of resources, then, is managed through the formation of social boundaries, to which members of a specific (sub-)group or entire community belong [65]. Being part of that community does not imply that one has the right to exclude others; 
however, it gives one the right to take part in decisions on resource conservation, regulation, and allocation $[37,66]$. Hence, these home-areas and their boundaries are relationally produced. To secure access to localized resources, access relations are also produced 'on the road' $[10,62,63,65,67]$. This, then, makes pastoralists perform an 'open engagement with space' [15] mainly based on 'relations, movements, and flows' [24], articulated through institutions. These institutions become the mediator between people and resources, and play a major role in defining the distribution of, and access to, resources [68,69]. It is important to note that often one can speak of an ideology of reciprocity, meaning that conditional access to resources in a home-area to members of one's wider social group is rarely refused $[5,7,70]$. Furthermore, governing mobility is mutually constitutive of the governance of grazing [7]. In addition to rules and regulations, or institutions, to manage and control access 'on the road', pastoralists traditionally produce spaces for the management and control of resources 'at home' [5,65]. Hence, in order to understand the institutions at work for access 'on the road', one has to understand the institutions in the home-areas as well.

\section{Methods and Context}

\subsection{Approach}

Fieldwork for this study was conducted in 2015 and partly in 2016 and 2017 in Samburu, Isiolo, and Laikipia. I spent a total period of 12 months in six sites along the mobility route of Samburu pastoralists within the Ewaso Nyiro (north) river basin [71-73]. For this paper, I held semi-structured in-depth interviews with Samburu pastoralists, including 17 women, 31 men, and 22 lmurrani $^{1}$. I interviewed elder men (from here referred to as 'elders', a category of local authority that consists of men above the age of 45) and women mainly at their homesteads ${ }^{2}$ to focus on narratives of change based on life-time memories, with a strong focus on the past 60 years of landscape changes and governmental interventions $[44,74,75]$. I also interviewed lmurrani who were moving with cattle herds in order to understand their movements across the landscape [76]. In total I conducted 70 interviews. Interviews were supported by four focus group discussions (FGD), one with women and one with elders in two sites, and participatory observation to obtain a detailed understanding of the landscape and daily interactions $[44,77]$. Furthermore, besides pastoralists, I also interviewed 20 key informants from governments and NGOs. Interviews in Samburu and Swahili were translated in situ by an experienced research assistant from the community, fluent in Samburu and English, of which a part were recorded with consent and transcribed at a later stage. Data was analysed, during and after fieldwork, through a manual coding system to categorize according to identified topics. This paper focuses on Sesia, although research did not confine itself to Sesia only, as I 'went along' with people and joined them on daily trips with their livestock, or met with them at places where they were setting up their temporary camps (lale), or at markets and meetings.

\subsection{Study Area}

The wider Ewaso ecosystem is part of the intersection between Samburu, Laikipia, and Isiolo Counties, connected by the Ewaso Nyiro (north) river flowing from south to northeast (Figure 1). This paper focuses on people from Samburu County, more specifically the area the Samburu refer to as the 'red lowlands', where Sesia is also located. Still, as the Samburu are semi-nomadic, mainly living within the arid and semi-arid area of Samburu, Isiolo, and Laikipia Counties in central-northern Kenya, they access resources at distant places within the wider region. Samburu County is administratively divided into three constituencies: Samburu East, North, and Central. Sesia is located in the Samburu

1 An lmurran [pl. Imurrani] is a circumcised and unmarried Samburu youth, of the age-grade between boyhood and junior elderhood, who is responsible for cattle herding and long distance migrations with livestock.

2 In Samburu, nkang' [pl. nkang'itie] refers to home, homestead or settlement. The nkang' often consists of various households. 
East constituency, and refers both to the Sesia sub-location and the Sesia group ranch. Sesia is part of the Meibae Conservancy.

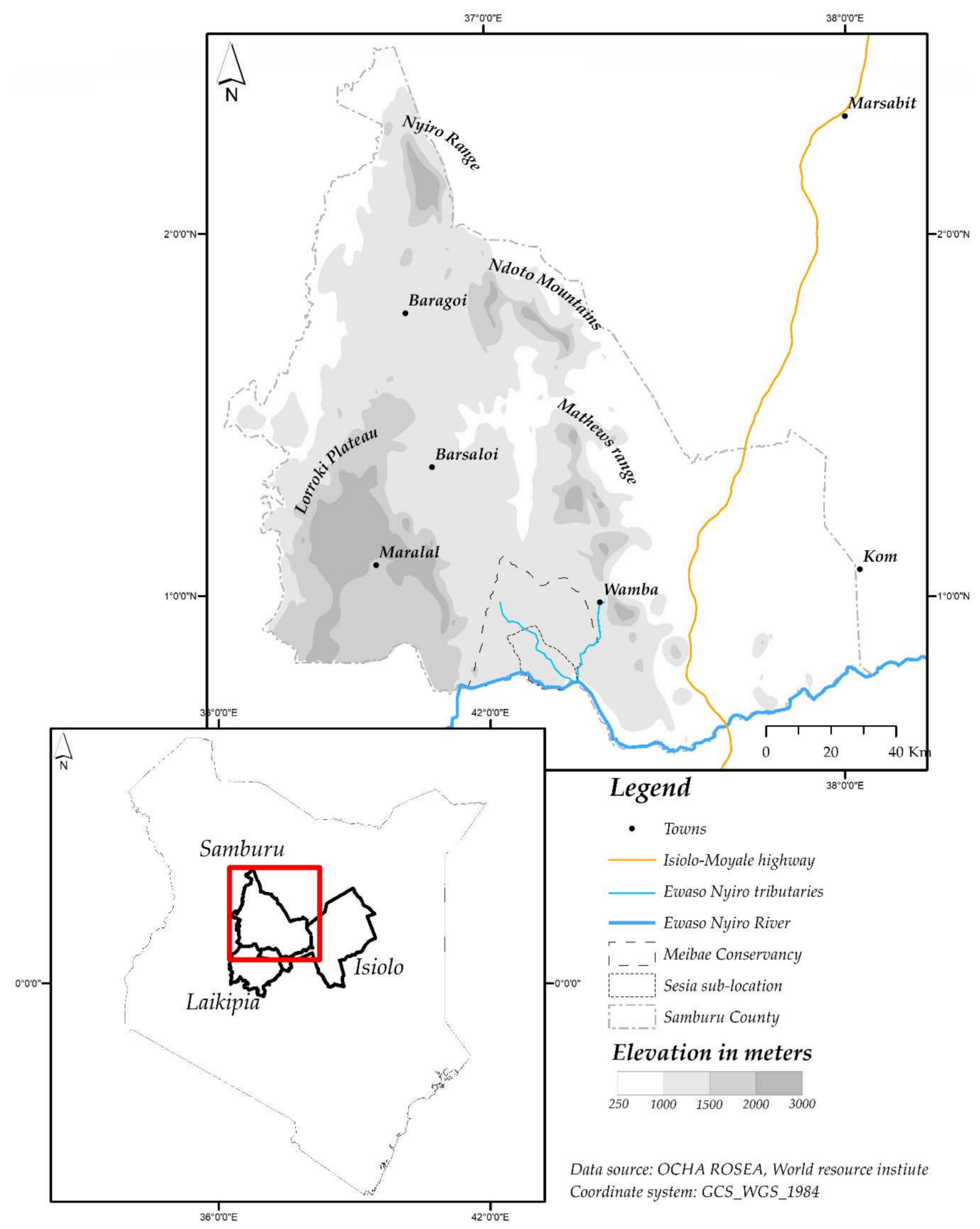

Figure 1. Sesia in Samburu, Kenya.

The Samburu population was approximately 223,947 in $2009,12 \%$ up from 2006, with a population density of 11 inhabitants per $\mathrm{km}^{2}$ [78]. The Samburu communities are heterogeneous and diverse. Social distinctions among the Samburu are formed around gender, age, clan, sub-clan, location of residence (highlands or lowlands), level of education, and economic position, among other factors [51,79-81]. These social distinctions have different meanings over time and shape the way individuals and groups respond to socio-political and environmental changes and the way they use natural resources [82-84]. Pastoralism is the main economic activity, with cattle, sheep, goats, and camels being the most important livestock. Herding is increasingly diversified on the Lorroki Plateau, 
specifically into rain-fed maize cropping, petty trade, livestock marketing, and tourism. Samburu living outside of these counties are often engaged in livelihood activities other than pastoralism, while sending remittances back home $[21,82,85,86]$.

Samburu County is approximately $21,000 \mathrm{~km}^{2}$, and is part of Rift Valley Province [78]. Marsabit is to the north-east, Turkana to the north-west, Baringo to the west, and Isiolo to the east. The Ewaso Nyiro River comprises the main southern boundary of Samburu, with Laikipia County finalizing the boundary to the south-east. Samburu County can be roughly divided into the highlands (ldonyo), with a general altitude of $1500 \mathrm{~m}$, including the Lorroki Plateau, and the lowland plains (lpurkel), with an altitude ranging between $1140 \mathrm{~m}$ and $1500 \mathrm{~m}$. The lowlands can be characterized by four different zones: the escarpment zone to the western edge of Samburu County; the mountain ranges at the eastern parts of the district, including the Nyiro Range (2709 m), the Ndoto Mountains (2595 m), and the Mathews Range (2337 m); the central plains, including the Lbarta Plains (Baragoi), the Swari Plains (Barsaloi), and lpurkel onyieki (red lowlands, named after the red desert soils southwest of Wamba); and lpurkel oibor (white lowlands, named after the white stony soil to the east of the Mathews Range), where elevation drops to $900 \mathrm{~m}$. The soils all over the lowlands are very poor, and fertile soils are found on Lorroki and the mountain ranges [46].

Generally, the highlands are cold and wet, with an annual rainfall of $1200 \mathrm{~mm}$, while the lowlands are hot and dry with precipitation averaging between $600 \mathrm{~mm}$ and $200 \mathrm{~mm}$. The highlands generally receive more rainfall because of the long rains ( $L n^{\prime}$ ger erwa) and the short rains (Lorikine and Ltumurin), in addition to several showers (Table 1). The lowlands, however, do not receive Lorikine and the dry season (Lamei Odo, or 'long hunger') is longer than in the highlands. The rainfall pattern is typified as tri-modal.

Table 1. Rainfall peaks in the lowlands and highlands of Samburu.

\begin{tabular}{lccccc}
\hline Season & $\begin{array}{c}\text { Ln'ger Erwa } \\
\text { (Long Rains) }\end{array}$ & $\begin{array}{c}\text { Lorikine } \\
\text { (Short Rains) }\end{array}$ & $\begin{array}{c}\text { Lamei Lo'odo } \\
\text { (Dry Season) }\end{array}$ & $\begin{array}{c}\text { Ltumurin } \\
\text { (Short Rains) }\end{array}$ & $\begin{array}{c}\text { Lamei Ndorop } \\
\text { (Dry Season) }\end{array}$ \\
\hline $\begin{array}{c}\text { Lowlands } \\
\text { (lpurkel) }\end{array}$ & April-May & - & June-October & October-December & January-March \\
\hline $\begin{array}{l}\text { Highlands } \\
\text { (ldonyo) }\end{array}$ & April-May & July-August & September-October + Showers ${ }^{1}$ & October-December & January-March + Showers \\
\hline $\begin{array}{l}\text { 1 Occasional showers (Nkokwai (June) Rurume (January), Somson Oibor (February), and Somson Orok (March)) are } \\
\text { more likely to fall on ldonyo. }\end{array}$ &
\end{tabular}

The highly-localized rainfall based on geographical and topographical locations results in micro-climates $[45,46]$. Furthermore, although erratic, a shift in rainfall has been observed over the past decade, with almost a complete loss of the short showers in the highlands and the lowlands ${ }^{3}$ [18].

Samburu living in the lowlands move within and beyond the area in order to profit from the topographically complex, but valuable, variation in climatic conditions and vegetation growth within this large area. Consecutive prolonged droughts in 1960, 1965, 1971 [46], and 1980, 1984, 1995, 2005, 2006, 2009, and 2011-2015 (a multiyear period of drought) ${ }^{4}$, impacted the amount of water and vegetation growth, and led to the loss of livestock. The droughts often last long, specifically in the lowlands, where rainfall is highly erratic and unreliable.

According to various studies and publications on historical vegetation in Samburu, the lowlands used to be a grass-dominated savannah with patches of woody vegetation, including dwarf bushes and shrubs, with the important Ltepes (Acacia tortilis) as dominant dryland tree mainly found along seasonal rivers $[16,46,48]$. In the hills and mountain ranges with higher rainfall within the lowlands, dense forests were-and still are-found, offering forage for livestock in times of drought ${ }^{5}$. Nowadays, the

\footnotetext{
Interview informant 3 and interview informant 13.

FGD Sesia, 12-13 October 2017.

Interview informant 14 and interview informant 9.
} 
lowlands are mainly covered with woody vegetation and annual grasses, suggesting land degradation. These woody trees and shrubs are green for longer periods of time compared to annual grasses, which only grow during the rainy seasons [87]. An increase in the Acacia reficiens has been detected, a species which is considered to curtail the regeneration of grasses and other valuable vegetation. Furthermore, after long periods of drought, surface runoff is common when rainfall on bare ground takes away fertile soil and stored seeds, leading to the formation of gullies, as well as the reduction of grasses and an increase in bushes and shrubs [16,46].

There is only one permanent river in the County, the Ewaso $\mathrm{Nyiro}^{6}$, while many small rivers and streams carry surface flow for only a few weeks each year (if not less). Smaller streams carry water after flash floods. The waterbeds of these seasonal rivers and streams hold saline water, which provides important minerals for livestock, and are accessible through wells dug by hand in the sand in the riverbeds. The river and wells form the major source of water for the people in the lowlands. Additionally, sand dams fill up with rainfall water for short periods of time. Boreholes are another source of water, funded by the local government or missionaries ${ }^{7}$.

\section{Grazing in Samburu}

\subsection{Historical Grazing and Mobility: Reciprocal Relations, Communal Grazing, and Restrictions}

In the past, and for the most part to date, mobility has been central in the lives of Samburu. Before colonial intervention in Samburu, Samburu pastoralists would regulate pastoral resources under communal tenure among members of the wider Samburu community, allowing access to different areas depending on rainfall and vegetation within Samburu territory. Entire families would move with their herds in groups. As one woman remembered:

"The home was moving bit by bit, to Loroshi, then to Ndigirr, then to Ngorungoru, then Matakweni, then to Ndigirr again, back to Matakwani, then to Sordo, then to Sarara, then to Sordo again, to Seramiti, Ndigirr, Nuash, Ndigirr again. There I gave birth to the first born and back to Seramiti where I gave birth to the second born. Then to Ndigirr, to Nanguarak, then there was a conflict with the Somali so I left to Ngankare. From that mijoni [abandoned homestead where there are still some structures standing], to that mijoni to that mijoni up here where we are now. Move, move, move. We were almost all over this area!" (Interview informant 21)

Herd mobility took place on a regular but gradual basis; during the rainy season or in areas where pastures were abundant, the elders set certain areas aside for either settlement or grazing. Following a system called enata nkop (restricted land), a specific area was restricted during the wet season in order to be grazed upon when the drought had set in. Only after the pasture inside the restricted area was gone would families continue to move again. One elder recalled:

"People restricting grazing areas was originally there even before the colonial government. People used to set aside a portion of land for grazing during the dry season. This was happening before the introduction of schemes and after. (... ) It was referred as enata nkop" (Interview informant 2)

In addition to enata nkop, through interviews I was also introduced to the system of lokere. Although later I will discuss the lokere as it is used currently, the lokere before colonial intervention was a communal institution where the sick, weak, and young animals from various families could be placed together. The difference between enata nkop and lokere was not always clear and the terms 6 Although lately showing signs of seasonality: in 2015 , the river was observed dry for the first time in living memory.
7 Interview informant 17 . 
were sometimes used interchangeably, though the lokere was more often identified as a fenced area. The lokere would be created at any place of settlement, as families were moving together. As an elder recounted:

"[T]he elders were cooperating; they were planning for grazing and settlement. In groups they would move on while grazing specific sites-moving step by step as they graze." (Interview informant 20)

Despite various forms of customary resource management, pastoralists were discursively construed as inferior and unable to manage and use such vast areas of land in an efficient and productive way [32,36], and colonial control over the Samburu people and their territory was mediated through grazing management and stock control to recover lands that were perceived by the colonial administration as 'devastated by over-grazing'. Strict destocking policies and grazing schemes were initiated [21,45,46]. The grazing schemes, initiated in 1936 in Lorroki and throughout the entire Samburu District in the 1950s, through various forms of grazing and stock control, became a highly contested and controversial issue between the colonial administrators and Samburu pastoralists. Areas with high-quality pasture and rainfall were demarcated within the bounded areas of the grazing schemes, which were subdivided into paddocks for rotational grazing, and where a quota of cattle was established to limit herd sizes. Other measures carried out by the colonial administration besides controlling grazing included fierce destocking policies and obligatory off-selling of livestock $[21,36,45,46]$. Each household was allowed a restricted number of animals, which had to graze within pre-defined areas at specific times of the year ${ }^{8}$. In 1960, 31.5\% of the entire Samburu District was under the control of grazing schemes, including the forest areas on the hillsides where grazing was forbidden. The general trend was an increase in livestock numbers outside of the schemes, in the more arid and uncontrolled areas. Dissatisfaction with the fierce destocking and grazing policies grew, and circumvention of the grazing regulations became a form of opposition. Resistance against grazing control became a strong disadvantage to the colonial administration, and after a serious drought, the grazing schemes were abandoned in $1961[36,45,88]$.

One elder, in describing the period after the abolition of the grazing schemes in Sesia, explained how the grazing schemes marked the separation between the lmurran and the family and, likewise, the start of sedentarization:

"When Lkishili was circumcised, schemes disappeared and we came to settle here. That was the time that the cattle started to move to mountains and other places, and children to stay with the women. This is how we slowly got into settlement; because if you were an elder before, you would go around with your animals, but now you would only let the lmurrani go. The schemes had made lmurrani to leave." [Interview informant 23]

In the years following independence, the new government did not interfere with grazing management and strategies in Samburu, neither in the lowlands nor the highlands. People could move freely over the landscape again and there were no restrictions on the number of livestock owned by individuals. Another elder informed me:

“Then we didn't follow any restrictions [regarding grazing]. It was time for Lkishili circumcision, so everybody went to his clan and didn't follow any plan. Just we settled with the clan. Immediately after the schemes ended, it rained El Niño and it was as if everywhere there was a [grazing scheme]. We had a lot of grass and rain so there was no need for restrictions or anything." (Interview informant 24)

This open engagement with space in which livestock movement occurred would still follow rules of sharing and reciprocity, though without significant restrictions for specified areas in the landscape.

8 Interview informant 15. 
After the rains stopped, however, mobility and Samburu grazing management institutions were quickly retained. Between 1961 and 1965, elders in Samburu lowlands decided to start managing settlement and grazing again through the customary communal regulation called nkwe ngishu ('head of a cow', keeping grass for cattle). One elder recounted:

"Then it was the plan of god to not give us rain. It is the plan of god to have the land the way it is now. Since then, we have started planning to settle in one area and leave another area for grazing, nkwe ngishu. So we can hold animals at home for some longer time." (Interview informant 24)

An nkwe ngishu area does not entail restricted grazing, as is the case with enata nkop, but restricted settlement; it is the area where one can bring their livestock (specifically cattle) for grazing, especially on the high-quality grazing sites. Hence, $n k w e$ ngishu, as still in use at the time of writing, is mainly a strategy to control the construction of homesteads, since settlement is not permitted in an area designated as nkwe ngishu. The $n k w e$ ngish $u$ area can shift over time, hence, it is not static in space. Another elder also said:

"Before and up to now, when it rains, there is a line where behind people are not supposed to settle, and another side where they are not supposed to graze with livestock. Such a line can be a river between the settlement and the grazing area. And grazing and settlement is divided." (Interview informant 8)

Thus nkwe ngishu, as an arrangement, is a term used to designate an area for cattle grazing in any place one happens to be. Although nkwe ngishu is mainly based on customary rules of resource allocation, it was also mentioned to be motivated by the colonial grazing schemes where settlement and grazing were strictly divided.

An elder explained to me that with time, however, it became harder to restrict settlement, and restrictions increasingly focused on grazing again, instead of on settlements:

"So everyone now started to settle here and there and everywhere, and the land started to deteriorate." (Interview informant 9)

In order to deal with increased sedentarization and declining resources, the Samburu, during the Lkororo age-set (initiated in 1977-1978), started to initiate the $m p a k a^{9}$, as based on the previously existing enata nkop, implying an area restricted for grazing. The mpaka was meant to reduce conflict occurring during cattle movements by making it possible for the cattle to be kept at home for longer periods of time. The mpaka system, as opposed to nkwe ngishu, is less flexible in space and refers to a restricted designated area. The designated area is restricted during the wet season for grasses to grow, to be grazed by cattle after the rains. Settling is not permitted in the mpaka, and livestock are only allowed once the elders have opened the mpaka for the community. Hence, mpaka is associated with strict boundaries and boundary control. There are diverging understandings of how the mpaka came to be. Although the term mpaka is the Swahili word for 'border', according to various informants, mpaka is derived from the English 'park' and has been given that name by the Samburu to relate to the national parks ${ }^{10}$, as they are known to be restricted areas where livestock cannot enter. One elder clarified:

"It was referred as enata nkop, meaning restricted area of which nowadays we call mpaka. This name mpaka originates from the Samburu National Reserve which was a restricted park. After the skimi [grazing schemes] we decided also to restrict these areas following the idea of colonial government as we have seen it was a good management of land." (Interview informant 2)

$9 \quad$ FGD Lekiji elders, 13 October 2017.

10 National parks are areas solely allocated by the government for wildlife conservation and management; human settlement is not allowed. 
As described, customary institutions from enata nkop —an area restricted in order to be grazed upon when the drought set in—and lokere—an area set aside especially for small and weak stock—gradually towards institutions as nkwe ngishu-restricting homestead formation in a specific area-and mpaka-a fixed, restricted area-that were more suitable to manage and deal with increasingly sedentary lifestyles.

\subsection{Post-Independence: Group Ranches and Conservancies}

At the same time the Samburu strengthened their customary institutions, the postcolonial government of Kenya introduced group ranches. The Kenyan government continued to view northern Kenya as an unproductive and particularly conflict-prone area over which the nation state had no control [89]. In 1972, under the Land (Group Representatives) Act of 1968, the Group Representative Officer started to demarcate land on Lorroki and in Baragoi Division for both individual and group ranches as a way to formalize land tenure. Group ranches are similar to grazing schemes in that they are a demarcated pasture area with the aim of controlling grazing, encouraging settlement, and commercializing livestock. Officially, group ranch management, control, and ownership are community-based instead of externally-owned and enforced. They were meant to link people to a specific area of land through the concept of membership, which would increase the sense of ownership and responsibility for the land. Similarly, through group ranches, land degradation could be controlled, decreasing the need for mobile pastoralism $[21,88,90,91]$.

The Sesia group ranch was initiated in 1976. I was repeatedly told that pastoralists initially did not like these boundary demarcations. As an elder told me:

"When the group ranch started, Lkishili [age-set] were lmurrani, only people from ldonyo [highlands] accepted them. We at lpurkel [lowlands] did not like it at all. We did not even like the introduction of the location [administrative boundaries]." (Interview informant 1)

Resistance against the introduction of group ranches took place by refusing to register as members. However, this did not lead to the rejection of this form of communal tenure, as a small group of elders did register, and so the Sesia group ranch came to exist. Two elders and one woman told me very clearly why they disliked the idea of a group ranch:

“When the group ranch started, many people really didn't like it because they thought land was to be taken away. Where would we graze the cow now? At the time, only five people were registered. Other people thought that one was signing for selling the land away." (Interview informant 24)

"It was believed that they participated in land division into group ranches after the white government left. During the introduction of Sesia group ranch, I remember people being called for membership registration but no one wanted to participate; luckily the secretaries and land officers managed to gather only ten people who represented Sesia group ranch." (Interview informant 2)

“In that time, people really refused. People didn't want even to know or hear about what this group ranch is. During that time we were not people who had gone to school, we didn't know people who had gone to school. So we did not know what is going on, so we didn't want it. We thought, this is the idea of the Kikuyu people who are coming to divide this land. Samburu people started to circulate the rumour that land will be divided, a portion to each individual, and only five cows were to be placed inside! Nobody wanted that." (Interview informant 22)

Hence, in 1976 only 37 people were registered as members of the Sesia group ranch, as they did not trust that the group ranch would be of benefit to them. Furthermore, as entire families were fully nomadic during the time of implementation, or have since migrated due to conflict, many Samburu 
pastoralists are registered in one group ranch while living in another. As a result, many residents of the Sesia group ranch are not members of the Sesia group ranch; they have moved over time towards these areas, but at the time of the group ranch introduction they were residing in Baragoi. One elder explained:

"We are members of Marti group ranch; it is our fathers' land because it is our fathers that are registered. Nobody lives there now because of the Turkana conflict, but we are still members there. We are not members here in Sesia and we are not sure if we will become members. ( ... ) Most people here are not registered as members but we have been in these areas for so long and we only wait for the registration to be announced and we go and register." (Interview informant 3)

Additionally, half a century later, after the establishment of group ranches in the Samburu lowlands, everyone is not yet a member of a group ranch and registration lists are incomplete. Since the initiation of the Sesia group ranch, the register only opened once more in 1994 when an additional 368 new members were registered. Since then, the registration book has stayed closed, even though more people want to become members. Over time, people gained more interest in it and saw benefits of being a member of a group ranch.

"We now understand about group ranches and we want everyone who is originally from this place to attain membership as we have known this is our own land and we have rights over it" (Interview informant 2)

In addition to the ability to claim ownership over land through group ranch membership, and the willingness to secure this ownership for future generations, other benefits of group ranches mentioned were the opportunity to gain a share in benefits when land within the group ranch is used for certain investments, such as a hotel, a lodge, or rented out for other projects, or to obtain compensation for construction works occurring within the group ranch. Some informants also mentioned how the acceptance of group ranches in the highlands made people in the lowlands also accept the group ranches.

In addition to local resistance against, and the process of delays in relation to, the instalment of certain group ranches, 17 of the 48 group ranches in Samburu have neither been approved nor received final adjudication by either the County Government or the District Government ${ }^{11}$, including Sesia. Partly as a result of this unfinished process, but also partly due to unfavourable weather conditions, among other factors, subdivision of group ranches has not taken place in the Samburu lowlands, as opposed to the developments that took place in the Samburu highlands [21] and in southern Kenya [92]. Although the process of final adjudication of group ranches will continue, the Community Land Act of 2016 might lift the process of finalization to the incomplete adjudication and registration of group ranches in Samburu [40]. This process, however, had not yet been set into motion during my stay.

Although, initially, the group ranches were not desired, their membership and boundary demarcation have gradually become of importance to the Samburu in the lowlands. However, it was not until the initiation of conservancies that the Sesia group ranch and its boundaries gained real importance in the lives of the people. Community conservancies are the newest form of natural resource governance in the region. A community conservancy is a demarcated area on community land introduced to stimulate nature and wildlife conservation with a key role for the local community. Conservancies are intended to improve local livelihoods, economic development, and peace through tourism and management and control of grazing in Samburu, among others, and are supported by the Northern Rangelands Trust (NRT) and Samburu County Government, who try to link the community with a private investor to assist with the start-up of a lodge, for example. These conservancies are

11 Interview informant 18. 
composed of one group ranch, or a conglomeration. Lekiji, for instance, which is located in the Sesia sub-location and is on the Sesia group ranch, and is part of the Meibae Conservancy, together with three other group ranches. As many women and elders told me, it was not until the demarcation of the conservancy boundaries that the exact location of the group ranch boundaries became clear. Hence, the conservancies brought the group ranch boundaries to life, bringing in a new form of spatial organization and related (promised) benefits, such as employment, profit sharing, bursaries, and improved grazing management.

\subsection{Current Grazing Institutions in Sesia: Enclosing Space}

Currently, in Sesia, land and grazing resources are managed and controlled following the rules and regulations of the customary institutions, the Sesia group ranch and the Meibae conservancy combined. Sesia consists of various small permanent towns, a gathering of various single and aggregated homesteads that, combined, form a neighbourhood, and in some cases with a school and a shop. One of these small towns is Lekiji. The communities within Lekiji decided over the use and management of resources together with another neighbourhood, Lkalkaloi. Samburu from Lekiji have a clear concept of their home-area. This home-area is not necessarily a fixed place, nor is it clearly defined by hard boundaries; it mainly relates to where one's family resides and where important ceremonies have taken place. These home-areas are made up of important points, specifically water, but also grazing points, which are tied to people living there and who have prior access and decision-making power over the area. As a woman told me:

"This is our place, nkop'ang [our land], you can go and graze together; it is open. I am from here, so here I don't have to negotiate [to access grazing]." (Interview informant 5)

Since the life of Samburu pastoralists in Sesia is organized in long-term settlements, the mpaka is effectively used in Lekiji. The community living in the wider Lekiji area is allowed to herd livestock in the mpaka once the elders have opened it. The mpaka is monitored by elders from the two villages, Lekiji and Lkalkaloi, and those caught grazing their cattle before the season has opened are chased out and have to pay a fine of three goats. Monitoring occurs to discourage livestock herding by members of the community, but also by other communities who cross the Ewaso Nyiro from Isiolo County when the water level is low or when the river is completely dry, as was the case in 2015. Members from other communities also have to pay a fine when they herd livestock in a closed mpaka. Currently, the term mpaka is also used to refer to the core conservation zone of the conservancy since, as in the case of the Meibae Conservancy, the same mpaka area has now become the core zone. In the Meibae Conservancy, where no tourism facility is constructed, the core conservation zone has the same function as the original mpaka: to restrict grazing in the area until the elders open it during the dry season.

Mpaka, nkwe ngishu, and the conservancy are institutions at a community level. Outsiders, then, will have to ask the authorities of Lekiji and Lkalkaloi for permission to set up a temporary livestock camp (lale) for livestock to graze and use water within that area. At the household level, there are two ways in which forage is managed: through the system of lokere, as introduced previously, and by the organization of the use of sagaram. The lokere is an area restricted through demarcation of branches by the thorny acacia bush. A lokere is nowadays constructed at the homestead level and only the livestock of that specific homestead are allowed to use the lokere, as opposed to prior to the grazing schemes, when the lokere was used communally. A lokere can be useful, specifically in the case of a shortage of herders to take care of the weaker animals, as its purpose is to enable the lkilepo (milking) herd, together with sick and young or old livestock (mostly cattle), to access grazing in the lokere. Therefore, the lokere is sometimes referred to as 'the hospital', as it is mainly for the young, old, and sick who cannot cross large distances to either recover or gain strength until the rains return. Previously, the lokere was also used for the maintenance of the weak stock. An elder remembered: 
"Lokere was also not preferred in the past since people believed that he who has a lokere must have a sick cow, a sick goat, or his cows would have broken limbs. It's like an open grave that desires something to be inside." (Interview informant 2)

However, conflicts tend to arise involving the lokere. I was told that when, for example, children herded goats and sheep, it often happened that these would enter a lokere and start grazing inside. This often created tensions between the owner of the lokere and the owner of the herd. Even more people started creating larger lokere, which restricted livestock movements and grazing patterns of other homesteads. Since 1996, in Lekiji and in wider Sesia, in order to avoid such conflicts, the lokere was abolished. There are places, however, where the use of a lokere is still allowed, for example, around towns where access to grazing is increasingly difficult. Even the lokere, just like mpaka and nkwe ngishu, is occasionally compared to the colonial grazing schemes. An elder told me:

"Are you seeing some green trees down there (pointing to near his homestead), on the 14 of March 1977, I started restricting that area. That is my lokere. Because I saw that during the schemes, this land was so good. And then I decided to preserve also this small side for my own benefit." (Interview informant 9)

Another way in which residents of Lekiji manage forage for their livestock is through controlling access to sagaram. Sagaram is a seed-pod from the Acacia tortilis, or Ltepes, a common and highly important tree in Samburu East. The acacia grows mainly along (seasonal) water streams and, hence cannot be found everywhere. The sagaram has always been an important kind of fodder-especially for goats and sheep-and, according to the informants, gained special protection and strict regulations in times of severe drought ${ }^{12}$. Nowadays, these regulations are year-round and include a strict sagaram season that is opened by the elders who also regulate the mpaka season; a ban on shaking the tree (to avoid the premature release of seedpods); and a clear demarcation of which tree can be used by which family or community. For example, if an acacia is located near a homestead, the members of this homestead are entitled to use the seedpods from this tree. Furthermore, in Sesia, where seasonal water streams perform the role of a boundary between two clans, the acacias on one side of the river are only used by the people living on that side of the river, and vice versa. Sagaram can be taken out of the trees with a stick, pushing the seedpods out. I was told that the restrictions on sagaram are highly valued, and they are considered the example to follow for pasture management, too.

During the dry season, or when necessary, the resources of the mpaka, and sagaram trees are allowed to be used. Access can be obtained upon request, hence, there are no exclusive rights; rather, there are prior access rights and the right to manage and control. Within a home-area, the members within that social network are allowed to use these resources if they follow the rules. The rules are enforced by local elders, who have the authority to announce restricted areas or resources as 'open' or 'closed'. Furthermore, outsiders have to request access from these elders if they wish to make use of the same pastures or resources as the local residents do.

However, prolonged droughts make it much harder to manage and restrict grazing areas. As one of the elders informed me:

"I also think this prolonged drought is disorganising people as elders plan their programs during wet seasons when everyone is at home. It is now one and half years that our cows are not at home, the rains have been failing all the time, Lorikine fails, Ltumurin fails, and $L n^{\prime}$ ger erwa fails. All of them fail and getting people together at home is hard as everybody is working harder for his or her livestock to survive drought." (Interview informant 2)

As can be seen, the previously 'more open' form of managing pasture for cattle, the nkwe ngishu, has been substituted by a stricter and 'closed' form, the less flexible and negotiable mpaka, where

12 FGD Sesia, 12-13 October 2017. 
boundaries and their enforcement play a stricter, more important role. The conversion of the mpaka into core conservancy zones with institutionalized rules or membership and clear boundaries, as well as ranger patrols, further enforces these boundaries. The communal abolition of the lokere is an important example of how restrictions can be reduced by engaging in a more 'open' way with space on communal basis, instead of enclosures on individual basis. Other forms of regulations to plan for sufficient grazing and forage for livestock are shifting as well, e.g., the restrictions on the sagaram that has become an increasingly important resource to be distributed equally when other nutritious vegetation is not available. With recurrent droughts and people being away from home often and for long periods because of prolonged droughts, the management of grazing is particularly challenging. Samburu from Lekiji find it difficult to implement grazing rules and regulations in the absence of any grass or people. Hence, during interviews, it became clear that their effective implementation only occurs during periods of rainfall, when people gather and plan the restriction of certain areas. Lack of rains, loss of vegetation, and an increase in consecutive and prolonged droughts have made the management of pasture difficult since planning can, and will, only occur after rain.

\subsection{Current Mobility and Access: Complex Distances and Conditional Provision of Access}

While people settle, livestock continues to move seasonally only with a section of the household, the Imurran. When the dry period sets in, the homestead will split the herd according to productivity and forage requirements. A herd composed of milking cows, young cows, and sick cows, together with the goats, sheep, camels, and donkeys, will stay at the homestead with the elders, women, and children, while the 'surplus' cattle herds will move with lmurrani to greener pastures. Hence, cattle will follow different patterns of migration following the lmurrani, who join in small groups to form a shared lale and organize their temporary homestead. They group with at least two to six lmurrani in order to share responsibilities and food. These groups shift over time and vary per year and location of migration. Only in extreme situations of drought will the women and elders move with the goats and sheep to lale in order to find available forage. Although this is rare, goat-lale-as adaptation to drought-has occurred increasingly since 2015, which demonstrates that it is becoming harder to find forage for goats near the homesteads. As a woman told me:

"Goat lale is something new. Very, very recent. Twenty to fifteen years ago, people who would go for goat lale would not go so far. But now, goat lale is very far, up to Kom people will go with their goats. Before, 15-20 years ago, they would go to find sagaram with the goats." (Interview informant 34)

Previously, the elders, who in principle are the herd-owners, were the main decision-makers on the movements of the cattle. Elders still have a say in the whereabouts of cattle, e.g., they may decide upon the movements and length of stay in certain places in order to regenerate grasses elsewhere. However, with the lmurrani being out with the cattle for most of the time, this has changed as well. As an elder clarified:

"Also in the past elders were very powerful compared to now. These days elders are less powerful, lmurrani are the one in charge of where to go and when to move with the cattle, they are conversant with the grazing areas as most of the time they are outside homes with the cattle. Elders, nowadays, we have strong power on conservancies that usually provides us with little grass which is not enough. (... ) Lmurrani are the one in control of the movement of livestock due to them being away from home for most of the time with cattle and they are given the authority to move with them as they have been moving across all this areas and they understand places that can sustain them for long time." (Interview informant 2)

Similarly, with the lmurrani moving a lot they spend most of their time in lale. This was not usual. As an elder remembered of the time he was an lmurran: 
"When I was an lmurran, it was an adventure to go for lale. You would choose to go for lale only to fatten cows, to activate the bull, to go on adventure, to get medicines from the forest, to get more milk for the lmurrani only-we would take many lactating cows ourselves and leave four or five cows behind. When the drought was severe, people move with cattle to the mountain and hillsides. But this was sometimes dangerous, and then only the lmurrani would go up with the cattle to set up lale, while the rest of the family would stay behind. But then a lot of changes happened in the past 20 to 30 years. With this shortage of grass, lale becomes a force." (Interview informant 25)

There is a significant shift in the role lale plays in daily life of the lmurrani, but also for the cattle and the people that are at home. People repeatedly informed me that nowadays, the cattle and the Imurrani were away from home all the time, and that the cattle have become used to going for lale. The woman and elders mentioned that they had missed two separate occasions of calf birthing. The movements with cattle are challenging for the lmurrani, having to spend long periods of time away from home and accessing grazing in particularly precarious places.

Still, the movement of livestock is carefully planned for, and deliberate choices and alterations between accessing water and accessing pastures are made on a daily basis. Besides available pastures, water, and knowledge of the area, it is the social connections that exist or are created ahead of moving the herd that are often of decisive importance. In case the chosen route leads to an area where a Samburu community resides, an lmurran will go scouting for pastures (saa), which includes making arrangements with the local communities about accessing grazing and water resources. Typically, the lmurran who went scouting will discuss with the elders of that specific community where to set up the lale, as well as the rules on grazing and water use that are to be followed according to the regulations of that community (e.g., not to graze in the local mpaka, in the core zone of the conservancy when applicable, or in the lokere, to respect seasonal rules of sagaram). These negotiations are of high importance to avoid future disputes. Grazing is in principle only provided based on understandings of reciprocity. An elder explained:

"We do allow them to graze here freely as long as they adhere to our rules and regulations. This is because they will also allow us to graze in their [group ranches] too when we do not have pasture in ours. We have no restriction on grazing across group ranches, we freely graze everywhere. We allow people to have grass in our group ranch whenever we have enough grass." (Interview informant 2)

Additionally, the moving herders are supposed to set up a lale in specific designated areas where they do not obstruct routes to water points nor reside near existing homesteads to avoid contamination and spread of diseases. Furthermore, water points are to be shared accordingly. Depending on the type of water point, the moving herders can either dig their own well in the river bed or use the permanent water point available. In the case of the latter, clear arrangements are made regarding which day the moving herd can go to the water point, and which day the local community will use it instead. Finally, the visiting herds are allowed to stay for as long as there is grazing available. However, if water is limited, the lmurrani are not supposed to stay long in that specific place, as the residing community has precedence over water usage. This occasionally leads to being driven away. As an lmurran told me:

“There are many places in between where people are not settled-so these are grazing areas for many different communities. However, also, such as the grazing area of Naisunyai, the neighbouring community of Naisunyai, they have their own wells for water, and they do not share that with visiting communities. So you can only stay there for two days because of lack of water and then you have to move on. The same in Sera, where you cannot graze because of the rhino sanctuary, and you are pushed away and have to move on. So, along the way there are some pushing places that make us move faster to the dry season grazing areas in Kom, Marti and Laikipia." (Interview informant 20) 
Another two lmurrani added:

"It is people who chase other people away because they live there. If there were no people, it is okay to be there." (Interview informant 19)

\section{Likewise:}

"They were pushing us away further for them to preserve grass for their cattle. Thinking that we will exhaust their grass and they will be left with nothing to graze their cattle" (Interview informant 29)

In addition to increased settlements which make it harder for lmurrani and their livestock to access grazing areas along the way, informants also mentioned that the conservancies and their related benefits and restrictions result in a form of access to grazing for members only. In relation to grazing, an elder told me:

"There is a small problem of the owners; when it is dry, there is an area that is called mpaka, which is grass only for the people from that area. The laleta are chased away from that place. So that the grass is for a few cows from Westgate only and not for the others." (Interview informant 23)

Furthermore, in relation to benefits accrued from conservancies, a woman explained ${ }^{13}$ :

"Yes it is free, you can go and graze on others peoples group ranch [conservancy]. There is no problem. Also people can come and graze also in Sesia if there is enough grass. But whenever there is an income for the group ranch, that is now where the problems start. They will say 'you do not belong here, so you should not benefit from this'. It is money that created the problem for grazing on other people's group ranch." (Interview informant 31)

Consequently, settlements, mpaka, the restrictions stemming from wildlife conservation areas, and membership-based benefits related to conservancies clearly make it harder for lmurrani and other herders to move on with their livestock over specific areas. As these places are increasing, there is also an increase in the driving away of Imurrani and other herders with their livestock to further places where there are no conservation areas or settlements. Moreover, grazing based on this principle of reciprocity is changing. There is a gradual change towards conditional provision of access. An elder informed me:

"Before we have been allowing people to graze freely and settle randomly where they would like to, but for now we have a policy that everybody should plan for their own grass as we are not going to share with them. We will not accommodate [other Samburu pastoralists] anymore so that at least our forage will last for a longer time. We are not going even to graze in their areas." (Interview informant 1)

Additionally, an lmurran told me that access should only be provided conditionally:

"It [mpaka] should be closed for a short time only, not for so long, because otherwise other people from other areas will come in and graze together with us and this is not good. We have conserved the grass for ourselves and then it will be finished in a very short period-and then we have to move." (Interview informant 19)

This conditional provision of access does not only count for pastures, as an elder added:

"We will not allow people to get our sagaram if they do not restrict it themselves." (Interview informant 32)

13 Note that 'group ranch' is used in order to refer to 'conservancy'. 
In other words, a clear understanding of boundaries and the people who belong with them has prompted this shift towards conditional provisioning of access. Only people from a particular community can use the nearby resources unconditionally, while people from other communities can only use those resources if they have restricted and managed their own resources as well. This new form of conditional provisioning of access to grazing is not always respected nor adhered to by lmurrani moving with cattle. Boundaries are crossed without consent and often by night. People also mention that this is a result of weakness and a lack of obedience to the elders. With the increase of boundaries and restricted areas, people are more likely to cross boundaries without consent and access sagaram before the season has opened, leading to an increase of fines, sanctions, and struggle.

In addition, instead of accessing pastures within Samburu County, which are either not available for outsiders or which have gone dry, lmurrani move with their herds to saatia: a place that has a large amount of grass. These areas are usually avoided, although they are considered 'sweet spots' and have some of the best forage available in large quantities. These border areas are unused due to diseases, conflict, or because there is no water available. As mentioned, the frontiers of Samburu County in Kom (bordering Isiolo County) and the Lbarta plains near Baragoi (bordering Turkana County) offer grazing sites where recurrent conflicts between other pastoral communities take place. People do not live here anymore due to hostile conflicts between the Samburu and the pastoral Borana and Turkana communities. These 'refuge' areas are grazed upon only during extreme drought when people have no other choice; they are dry-year places and are not considered to be part of the routinely-chosen spots for easy grazing. Mostly, an lmurran will only go to saatia if he has arms at his disposal. Laikipia is also considered a saatia with a large amount of pasture, although here the pastures are privately owned for ranching and/or conservation and tourism purposes. On private land, lmurrani bring their cattle to graze at night. In some cases, lmurrani are arrested and have to pay heavy fines for trespassing. An one lmurran informed me:

"We just go around these plains during the day and we graze at night in the ranches." (Interview informant 28)

It can be concluded that it came to a point where the herders with cattle, and increasingly with goats, have to be on the move all the time. The family wants their animals and lmurrani to be at home. The lmurrani themselves want to be at home to sing, to dance, and to drink milk together with the rest of the family. Instead of herding cows in distant places, many lmurrani prefer to stay home and take care of the goats and camels. As a number of Imurrani told me:

"It is getting hard, because the cattle takes you to a place where it is hot and fight with people. You go to Kom, you fight, you go to Baragoi, you fight, you go to Laikipia, it is a problem too. We do not know now what to do with the cows." (Interview informant 19)

In the same way:

"[W]ho wants to buy cows now? You better buy camels! Cows [sigh]... they can take you to Kom, to Baragoi ..." (Interview informant 12)

\section{Discussion}

\subsection{Reciprocal Relations and Enclosing Space}

Customary institutions to manage and access grazing still appear to play an important role in the governance of resources in the lowlands of Samburu. There is a general perception, however, that these institutions have changed significantly over time. Given the explanations of informants, changing weather conditions, permanent settlements, but also (post)colonial interventions have, combined, played a role in the shifting practices of grazing management and mobility. Whereas previously-restricted areas were rather flexible in space, such as the enata nkop and lokere, gradually these were exchanged for institutions that are more fixed in space, such as the nkwe ngishu and mpaka. 
Apparently, the shift towards less flexible institutions came along with increasing sedentarization and permanent settlements of the Samburu pastoralists. In addition, colonial and post-colonial interventions, which introduced spatial boundaries aimed at fixing spaces for grazing and settlement, may also have resulted in an increase of sedentary lifestyles and motivated, locally, a strict division of settlement and grazing as well. Initially, these boundaries did not withhold Samburu from practicing mobility based on rules of reciprocity. Based on reciprocal relations and the rule of elders, mobility and access to resources in areas where other members of the Samburu community were residing continued to take place. While settlement increased, and grazing areas were strictly controlled by the elders, weather conditions also marked changes and access to resources became more complex. Livestock mobility involved longer distances and it became more difficult for the elders to maintain strict rules over restricted grazing areas for two reasons. Firstly, as people and livestock were more often away from home it became more difficult to organize and regulate restricted areas. Secondly, the boundaries of restricted areas were more often crossed without permission of the elders. This suggests a general weakening of the control of elders over customary institutions. In contrast, however, the abolition by the elders of the individual lokere shows that the elders continue to have a say in matters related to the enclosing of space. It may also suggest that the lokere, as it is an enclosed space on individual basis, has relatively little support at community level as it does not benefit the community as a whole. The lokere, then, instead of providing grazing and other benefits to the entire community, such as those the mpaka is supposed to bring, is only to the benefit of those who are able to maintain a lokere. Additionally, as it brought a great deal of struggle and conflict among members of the community, the decision by the elders to abolish the lokere gained significant support from within the community. At the same time, this might explain why other enclosures, such as the mpaka and nkwe ngishu, are not abolished by the elders.

\subsection{New Rules of Access}

The findings suggest that, while livestock mobility involves longer periods and more complex distances due to a shrinking resource base, the value of reciprocity is eroding. With the introduction of group ranches, followed by conservancies, other layers of boundaries were introduced in the landscape. Although the current conservancy boundaries already existed prior to their introduction of conservancies, their meaning and interpretation changed: the boundaries became a marker to identify who is entitled to the benefits accruing from the conservancies, and who is not. Hence, reciprocity as a form of mutual access to resources has gradually been replaced by conditional provision of access. While reciprocity is eroding, there is a continuous trend towards a more rigid understanding of spatial boundaries demarcated on the land leading to a 'closed engagement with space' $[15,24,93]$. This closed engagement delineates a stronger connection to a certain place where clear spatial boundaries are drawn and bounded territories are formed. Where, previously, access was guaranteed based on social networks and relations of reciprocity, there are now processes of exclusion at play, implying a different approach to access resources. Instead of providing access to fluctuating resources, as was initially the case, processes of exclusion imply a stronger focus on the land itself [62]. Group ranches and their (externally-initiated) transformation into conservancies are currently of great importance for such processes of conditional access, fuelling struggle, and conflict. Despite the transformations, boundaries are crossed at times legitimately or illegitimately.

Furthermore, this case illustrated that changing socio-political and environmental circumstances affect natural resource governance and access, involving spatial reconfiguration. This shifting engagement with space, however, is not merely a result of (post)colonial policies and practices gradually changing Samburu resource governance and territories, but also the interpretation and implementation by Samburu pastoralists and their strategies to reach their own goals, as can also be seen in other examples where certain processes and interventions create openings on the ground for processes of boundary making and struggles over resource access, power, and space [24,66,93-95]. However, although the conditional provision of access might seem valid, conditionality might not 
be the most suitable way to control access in a landscape where rainfall is heavily fluctuating in time and space. Restoring and strengthening values, such as reciprocity, could overcome strict membership-based access, and seeing the separated conservancies and home-areas as part of a connected and integrated landscape instead of a grid of enclosures could bring back a more open engagement with space, which is of vital importance to pastoralists in the drylands. Even though mobility is evidently of major importance to pastoralists living in drylands, policy and project implementation has historically been driven by the imperative to secure land tenure and improve pasture in bounded areas. Although the Kenyan government has shown an interest in pastoral livelihoods, and suitable policies for the development of pastoral areas have followed, opportunities to support institutions that promote mobility have been given insufficient attention. Policies still reflect the need to 'improve the rangelands' through management of grazing, and the securitization of tenure through both land rights and ownership in an enclosed manner, as opposed to the management and support of mobility strategies and institutions $[7,15,41,45,46]$. Hence, the inherent paradox whereby policies for securing access to resources generally go hand-in-hand with an increase in spatial boundaries that limit mobility and tend to result in growing uncertainties in terms of access to grazing and water [96]. Therefore, State policy and legislation on how to secure tenure to mobile pastoralists should start to include support for livestock mobility within and between pastoralist communities in order to foster mutual sharing. This includes regulations among communities to enhance mobility as a way to overcome the boundaries that have come to exist. By-laws based on customary forms of mobility and grazing management, for example, could be formulated in a truly participatory way by the local government and the organization responsible for initiating the conservancies. In doing so, closer attention should be given to what factors actually support, and limit, livestock mobility. Furthermore, governing mobility is mutually constitutive of the governance of rangelands [7]. Hence, livestock mobility will enhance the regeneration of grazing resources. Additionally, the securitization of land at the regional and national scales should occur without the need to fix people to specific bounded spaces, and the violation of pastoralist land use and ownership should carry heavier penalties.

\section{Conclusions}

This paper has provided a deeper understanding of shifting engagements with space by focusing on new sets of relations that emerge in the processes of gaining and controlling access to resources. I conclude that livestock mobility for Samburu pastoralists in the lowlands involves longer periods and more complex distances due to a shrinking resource base and new rules of access. Communal grazing and pasture management institutions are (re)formed and (re)enacted in this increasingly enclosed landscape. Access to pastures and water has to be negotiated beyond social networks. Processes of inclusion and exclusion do not solely follow the pastoral logic of reciprocity, which is becoming less common. Instead, access is based on an increasingly complex set of interactions, relations, and boundaries, which makes it more difficult to maintain access to pastures and water. Furthermore, as recurrent droughts and livestock losses continue, herders are turning to crossing boundaries without permission to access pastures, leading to increased struggle and conflict.

As argued at the beginning of this article, livestock mobility is of vital importance to Samburu pastoralists. Due to related struggle and conflict occurring in the landscape, and the complexity of colonial legacies, State policy, biodiversity and wildlife conservation, and local interpretations and processes, it is urgent to identify appropriate strategies to support such livestock mobility. These strategies must operate locally while being connected with socio-environmental and political processes within the wider landscape. As a result of conducting this research, I propose that policy emphasis is given to locally-formulated by-laws which support reciprocal use and access of resources as a means to strengthen landscape-level interconnectivity integrating people, land, and resources. At regional and national scales, these by-laws will have to be incorporated into relevant social and environmental policy and planning documents. 
Acknowledgments: This paper benefited from constructive comments and support by Lowe Börjeson, Liz Watson, and William Gibbs, as well as three anonymous reviewers. I thank my research assistant and informants who were willing to share their time with me, and also Tomas Pickering and Kasmira Cockerill, among others, for their valuable discussions and constructive cooperation. This work was supported by the Marie Skłodowska-Curie Actions Resilience in East African Landscapes (REAL) Innovative Training Network funded by the European Commission [FP7-PEOPLE-2013-ITN project no. 606879].

Conflicts of Interest: The author declares no conflict of interest.

\section{References}

1. Homewood, K.M. Policy, environment and development in African rangelands. Environ. Sci. Policy 2004, 7, 125-143. [CrossRef]

2. Ellis, J.E.; Swift, D.M. Stability of African pastoral ecosystems: Alternate paradigms and implications for development. Rangel. Ecol. Manag. J. Range Manag. Arch. 1988, 41, 450-459. [CrossRef]

3. Behnke, R.H.; Scoones, I.; Kerven, C. Range Ecology at Disequilibrium: Newe Models of Natural Variability and Pastoral Adaptation in African Savannas; Overseas Development Institute for the Overseas Development Institute, the International Institute for Environment and Development and the Commonwealth Secretariat: London, UK, 1993; p. 259.

4. Zimmerer, K.S. The Reworking of Conservation Geographies: Nonequilibrium Landscapes and Nature-Society Hybrids. Ann. Assoc. Am. Geogr. 2000, 90, 356-369. [CrossRef]

5. Galaty, J. The indigenisation of pastoral modernity: Territoriality, mobility, and poverty in dryland Africa. In Pastoralism in Africa: Past, Present and Future; Bollig, M., Schnegg, M., Wotzka, H., Eds.; Berghahn Books: New York, NY, USA, 2013; pp. 473-510.

6. Butt, B. Ecology, mobility and labour: Dynamic pastoral herd management in an uncertain world. Rev. Sci. Tech. 2016, 35, 461-472. [CrossRef] [PubMed]

7. Turner, M.D. The New Pastoral Development Paradigm: Engaging the Realities of Property Institutions and Livestock Mobility in Dryland Africa. Soc. Nat. Resour. 2011, 24, 469-484. [CrossRef]

8. Watson, E.E.; Kochore, H.H.; Dabasso, B.H. Camels and Climate Resilience: Adaptation in Northern Kenya. Hum. Ecol. 2016, 44, 701-713. [CrossRef] [PubMed]

9. Vehrs, H.; Heller, G.R. Fauna, Fire, and Farming: Landscape Formation over the Past 200 years in Pastoral East Pokot, Kenya. Hum. Ecol. 2017, 45, 613-625. [CrossRef]

10. Scoones, I. Ecological dynamics and grazing-resource tenure: A case study from Zimbabwe. In Managing Mobility in African Rangelands. The Legitimization of Transhumance, 1st ed.; Niamir-Fuller, M., Ed.; Intermediate Technology Publications Ltd. (ITP): London, UK, 1999; pp. 217-235.

11. Sullivan, S.; Homewood, K. On Non-Equilibrium and Nomadism: Knowledge, Diversity and Global Modernity in Drylands (and Beyond ... ); Working Paper No. 122/03; CSGR: Coventry, UK, 2003.

12. Galvin, K.A.; Reid, R.S.; Behnke, R.; Hobbs, N.T. Fragmentation in Semi-Arid and Arid Landscapes. Consequences for Human and Natural Systems; Springer: Dordrecht, The Netherlands, 2008; p. 411.

13. Reid, R.S.; Fernández-Giménez, M.E.; Galvin, K.A. Dynamics and Resilience of Rangelands and Pastoral Peoples Around the Globe. Ann. Rev. Environ. Resour. 2014, 39, 217-242. [CrossRef]

14. Catley, A.; Lind, J.; Scoones, I. Pastoralism and Development in Africa: Dynamic Change at the Margins; Routledge: Abingdon, UK, 2013; p. 295.

15. Watson, E.E. A "hardening of lines": Landscape, religion and identity in northern Kenya. J. East. Afr. Stud. 2010, 4, 201-220. [CrossRef]

16. Kimiti, D.W.; Hodge, A.C.; Herrick, J.E.; Beh, A.W.; Abbott, L.E. Rehabilitation of community-owned, mixed-use rangelands: Lessons from the Ewaso ecosystem in Kenya. Plant Ecol. 2017, 218, 23-37. [CrossRef]

17. Lovett, J.C. Modelling the effects of climate change in Africa. Afr. J. Ecol. 2015, 53, 1-2. [CrossRef]

18. Pricope, N.G.; Husak, G.; Lopez-Carr, D.; Funk, C.; Michaelsen, J. The climate-population nexus in the East African Horn: Emerging degradation trends in rangeland and pastoral livelihood zones. Glob. Environ. Chang. 2013, 23, 1525-1541. [CrossRef]

19. Bottazzi, P.; Goguen, A.; Rist, S. Conflicts of customary land tenure in rural Africa: Is large-scale land acquisition a driver of 'institutional innovation'? J. Peasant Stud. 2016, 43, 971-988. [CrossRef]

20. Greiner, C.; Mwaka, I. Agricultural change at the margins: Adaptation and intensification in a Kenyan dryland. J. East. Afr. Stud. 2016, 10, 130-149. [CrossRef] 
21. Lesorogol, C.K. Contesting the Commons: Privatizing Pastoral Lands in Kenya; University of Michigan Press: Ann Arbor, MI, USA, 2008; p. 264.

22. Woodhouse, P.; Bernstein, H.; Hulme, D. African Enclosures? The Social Dynamics of Wetlands in Drylands; James Currey: Oxford, UK, 2000; p. 238.

23. Mwangi, E. The puzzle of group ranch subdivision in Kenya's Maasailand. Dev. Chang. 2007, 38, 889-910. [CrossRef]

24. Korf, B.; Hagmann, T.; Emmenegger, R. Re-spacing African drylands: Territorialization, sedentarization and indigenous commodification in the Ethiopian pastoral frontier. J. Peasant Stud. 2015, 42, 881-901. [CrossRef]

25. Brottem, L.V. Environmental Change and Farmer-Herder Conflict in Agro-Pastoral West Africa. Hum. Ecol. 2016, 44, 547-563. [CrossRef]

26. Turner, M.D. Political ecology and the moral dimensions of "resource conflicts": The case of farmer-herder conflicts in the Sahel. Political Geogr. 2004, 23, 863-889. [CrossRef]

27. Mosley, J.; Watson, E.E. Frontier transformations: Development visions, spaces and processes in Northern Kenya and Southern Ethiopia. J. East. Afr. Stud. 2016, 10, 452-475. [CrossRef]

28. Enns, C. Infrastructure projects and rural politics in northern Kenya: The use of divergent expertise to negotiate the terms of land deals for transport infrastructure. J. Peasant Stud. 2017, 1-19. [CrossRef]

29. Greiner, C. Pastoralism and Land-Tenure Change in Kenya: The Failure of Customary Institutions. Dev. Chang. 2017, 48, 78-97. [CrossRef]

30. African Union. Policy Framework for Pastoralism in Africa: Securing, Protecting and Improving the Lives, Livelihoods and Rights of Pastoralist Communities; African Union: Addis Ababa, Ethiopia, 2013.

31. Elmi, M.; Birch, I. Creating Policy Space for Pastoralism in Kenya; Future Agricultures Consortium: Brighton, UK, 2013; pp. 1-28.

32. Anderson, D.M. Cow power: Livestock and the pastoralist in Africa. Afr. Aff. 1993, 92, 121-133. [CrossRef]

33. Hardin, G. The Tragedy of the Commons. Science 1968, 162, 1243-1248. [CrossRef] [PubMed]

34. Herskovits, M.J. The cattle complex in East Africa. Am. Anthropol. 1926, 28, 230-272. [CrossRef]

35. Lamprey, H. Pastoralism yesterday and today: The over-grazing problem. Ecosyst. World 1983, 13, 643-666.

36. Waweru, P. Continuity and Change in Samburu Pastoralism: Under Colonial Rule, C. 1909-1963; LAP, Lambert Academic Publishing: Saarbrücken, Germany, 2012; p. 292.

37. Niamir-Fuller, M.; Turner, M.D. A review of recent literature on pastoralism and transhumance in Africa. In Managing Mobility in African Rangelands: The Legitimization of Transhumance; Niamir-Fuller, M., Ed.; Intermediate Technology Publications Ltd. (ITP): London, UK, 1999; pp. 18-46.

38. Odhiambo, M.O. Moving beyond the Rhetoric: The Challenge of Reform in Kenya's Drylands; IIED Briefing: London, UK, 2013.

39. Odhiambo, M.O. The Unrelenting Persistence of Certain Narratives: An Analysis of Changing Policy Narratives about the ASALs in Kenya; A Position Paper Prepared for the New Perspectives on Climate Resilient Drylands Development Project; IIED: London, UK, 2013.

40. Republic of Kenya. The Community Land Act; Government Printer: Nairobi, Kenya, 2016.

41. Fratkin, E.; Roth, E.A. As Pastoralists Settle: Social, Health, and Economic Consequences of the Pastoral Sedentarization in Marsabit District, Kenya; Kluwer Academic Publishers: New York, NY, USA, 2005; p. 280.

42. Haller, T.; Van Dijk, H.; Bollig, M.; Greiner, C.; Schareika, N.; Gabbert, C. Conflicts, security and marginalisation: Institutional change of the pastoral commons in a 'glocal' world. Rev. Sci. Tech. 2016, 35, 405-416. [CrossRef] [PubMed]

43. Adger, W.N.; Huq, S.; Brown, K.; Conway, D.; Hulme, M. Adaptation to climate change in the developing world. Prog. Dev. Stud. 2003, 3, 179-195. [CrossRef]

44. Krätli, S. Discontinuity in pastoral development: Time to update the method. Rev. Sci. Tech. 2016, 35, 485-497. [CrossRef] [PubMed]

45. Spencer, P. Nomads in Alliance. Symbiosis and Growth among the Rendille and Samburu of Kenya; Oxford University Press: Londen, UK, 1973; p. 230.

46. Fumagalli, C.T. A Diachronic Study of Change and Socio-Cultural Process among the Pastoral Nomadic Samburu of Kenya, 1900-1975; State University of New York: Buffalo, NY, USA, 1977.

47. Perlov, D.C. Trading for Influence: The Social and Cultural Economics of Livestock Marketing among the Highland Samburu of Northern Kenya. Ph.D. Thesis, University of California, Los Angeles, CA, USA, 1987. 
48. Barkham, J.; Rainy, M. The vegetation of the Samburu-Isiolo Game Reserve. Afr. J. Ecol. 1976, 14, $297-329$. [CrossRef]

49. Sperling, L. Food acquisition during the African drought of 1983-1984: A study of Kenyan herders. Disasters 1987, 11, 263-272. [CrossRef]

50. Sperling, L. The adoption of camels by Samburu cattle herders. Nomadic Peoples 1987, 23, 1-17.

51. Straight, B.S. Altered Landscapes, Shifting Strategies: The Politics of Location in the Constitution of Gender, Belief, and Identity Among the Samburu Pastoralists in Northern Kenya; University of Michigan: Ann Arbor, MI, USA, 1997.

52. Straight, B.; Lane, P.; Hilton, C.; Letua, M. “Dust people”: Samburu perspectives on disaster, identity, and landscape. J. East. Afr. Stud. 2016, 10, 168-188. [CrossRef]

53. Fratkin, E. Pastoral Land Tenure in Kenya: Maasai, Samburu, Boran, and Rendille Experiences, 1950-1990. Nomadic Peoples 1994, 55-68.

54. Lesorogol, C.K. Transforming institutions among pastoralists: Inequality and land privatization. Am. Anthropol. 2003, 105, 531-541. [CrossRef]

55. Lengoiboni, M.; van der Molen, P.; Bregt, A. Pastoralism within the cadastral system: Seasonal interactions and access agreements between pastoralists and non-pastoralists in Northern Kenya. J. Arid Environ. 2011, 75, 477-486. [CrossRef]

56. Butt, B.; Shortridge, A.; WinklerPrins, A.M. Pastoral herd management, drought coping strategies, and cattle mobility in southern Kenya. Ann. Assoc. Am. Geogr. 2009, 99, 309-334. [CrossRef]

57. Homewood, K.; Trench, P.C.; Kristjanson, P. Staying Maasai? Livelihoods, Conservation, and Development in East African Rangelands; Springer: New York, NY, USA, 2009; p. 418.

58. Li, T.M. Land's end: Capitalist Relations on an Indigenous Frontier; Duke University Press: London, UK, 2014; p. 240.

59. Sikor, T.; Lund, C. Access and Property: A Question of Power and Authority. Dev. Chang. 2009, 40, 1-22. [CrossRef]

60. Ribot, J.C.; Peluso, N.L. A Theory of Access. Rural Sociol. 2003, 68, 153-181. [CrossRef]

61. Niamir-Fuller, M. Managing mobility in African rangelands. In Managing Mobility in African Rangelands: The Legitimization of Transhumance; Niamir-Fuller, M., Ed.; Intermediate Technology Publications Ltd. (ITP): London, UK, 1999; pp. 102-131.

62. Ingold, T. Territoriality and tenure: The appropriation of space in hunting and gathering societies. In The Appropriation of Nature: Essays on Human Ecology and Social Relations; Ingold, T., Ed.; University of Iowa Press: Iowa City, IA, USA, 1986; pp. 130-164.

63. Van Dijk, H. Land tenure, territoriality and ecological instability: A Sahelian case study. In The Role of Law in Natural Resource Management; Spiertz, J., Wiber, M.J., Eds.; VUGA: The Hague, The Netherlands, 1996; pp. 17-45.

64. Casimir, M.J. The Dimensions of Territoriality: An Introduction. In Mobility and Territoriality. Social and Spatial Boundaries among Foragers, Fishers, Pastoralists and Peripatetics; Casimir, M.J., Rao, A., Eds.; Berg Publishers: Oxford, UK, 1992; pp. 1-26.

65. Casimir, M.J. The Determinants of Rights to Pasture: Territorial Organisation and Ecological Constraints. In Mobility and Territoriality. Social and Spatial Boundaries among Foragers, Fishers, Pastoralists and Peripatetics; Casimir, M.J., Rao, A., Eds.; Berg Publishers: Oxford, UK, 1992; pp. 153-204.

66. Marin, A.; Bjørklund, I. A tragedy of errors? Institutional dynamics and land tenure in Finnmark, Norway. Int. J. Commons 2015, 9, 19-40. [CrossRef]

67. Karplus, Y.; Meir, A. The Production of Space: A Neglected Perspective in Pastoral Research. Environ. Plan. D Soc. Space 2013, 31, 23-42. [CrossRef]

68. Leach, M.; Mearns, R.; Scoones, I. Environmental Entitlements: Dynamics and Institutions in Community-Based Natural Resource Management. World Dev. 1999, 27, 225-247. [CrossRef]

69. Young, O.R. International Governance: Protecting the Environment in a Stateless Society; Cornell University Press: Ithaca, NY, USA, 1994; p. 221.

70. Moritz, M. Open property regimes. Int. J. Commons 2016, 10, 688-708. [CrossRef]

71. Yin, R.K. Case Study Research: Design and Methods; Sage Publications: Thousand Oaks, CA, USA, $1994 ;$ p. 171.

72. Gagnon, Y. The Case Study as Research method: A Practical Handbook; Presses de l'Université du Québec: Québec, QC, Canada, 2010; p. 130. 
73. Ericksen, P.; de Leeuw, J.; Said, M.; Silvestri, S.; Zaibet, L. Mapping ecosystem services in the Ewaso Ng'iro catchment. Int. J. Biodivers. Sci. Ecosyst. Serv. Manag. 2012, 8, 122-134. [CrossRef]

74. Dunn, K. Interviewing. In Qualitative Research Methods in Human Geography; Hay, I., Ed.; Oxford University Press: Melbourne, Australia, 2000; pp. 50-82.

75. Li, T.M. The Will to Improve: Governmentality, Development, and the Practice of Politics; Duke University Press: North Dakham, NC, USA, 2007; p. 374.

76. Evans, J.; Jones, P. The walking interview: Methodology, mobility and place. Appl. Geogr. 2011, 31, 849-858. [CrossRef]

77. Cameron, J. Focussing on the Focus Group. In Qualitative Research Methods in Human Geography, 2nd ed.; Hay, I., Ed.; Oxford University Press: Melbourne, Australia, 2005; pp. 116-132.

78. Kenya National Bureau of Statistics. Population and Housing Census of Kenya, 2009: Volume 1A Population Distribution by Administrative Units; Government Printer: Nairobi, Kenya, 2010.

79. Spencer, P. The Samburu: A Study of Gerontocracy in a Nomadic Tribe; Routledge: New York, NY, USA, 2004; p. 384.

80. Meiu, G.P. Ethno-Erotic Economies: Sexuality, Money, and Belonging in Kenya; University of Chicago Press: Chicago, IL, USA, 2017; p. 304.

81. Holtzman, J. Uncertain Tastes: Memory, Ambivalence, and the Politics of Eating in Samburu, Northern Kenya; University of California Press: Berkeley, CA, USA, 2009; p. 296.

82. Little, P.D.; Smith, K.; Cellarius, B.A.; Coppock, D.L.; Barrett, C. Avoiding Disaster: Diversification and Risk Management among East African Herders. Dev. Chang. 2001, 32, 401-433. [CrossRef]

83. Holtzman, J. Eating Time: Capitalist History and Pastoralist History among Samburu Herders in Northern Kenya. J. East. Afr. Stud. 2007, 1, 436-448. [CrossRef]

84. Ongoro, E.B.; Ogara, W. Impact of climate change and gender roles in community adaptation: A case study of pastoralists in Samburu East District, Kenya. Int. J. Biodivers. Conserv. 2012, 4, 78-89.

85. Karanja Ng'ang'a, S.; Bulte, E.H.; Giller, K.E.; McIntire, J.M.; Rufino, M.C. Migration and Self-Protection Against Climate Change: A Case Study of Samburu County, Kenya. World Dev. 2016, 84, 55-68. [CrossRef]

86. Meiu, G.P. 'Beach-Boy Elders' and 'Young Big-Men': Subverting the Temporalities of Ageing in Kenya's Ethno-Erotic Economies. Ethnos 2015, 80, 472-496. [CrossRef]

87. McCabe, J.T. Cattle Bring Us to Our Enemies: Turkana Ecology, Politics, and Raiding in a Disequilibrium System; University of Michigan Press: Ann Arbor, MI, USA, 2004; p. 301.

88. Fumagalli, C.T. An evaluation of development projects among East African pastoralists. Afr. Stud. Rev. 1978, 21,49-63. [CrossRef]

89. Whittaker, H.A. The socioeconomic dynamics of the shifta conflict in Kenya, c. 1963-8*. J. Afr. Hist. 2012, 53, 391-408. [CrossRef]

90. Rutten, M. Selling Wealth to Buy Poverty: The Process of the Individualization of Landownership among the Maasai Pastoralists of Kajiado District, Kenya, 1890-1990; Breitenbach: Saarbrücken, Germany, 1992.

91. Letai, J.; Lind, J. Squeezed from all sides: Changing resource tenure and pastoralist innovation on the Laikipia Plateau, Kenya. In Pastoralism and Development in Africa. Dynamic Change at the Margins; Catley, A., Lind, J., Scoones, I., Eds.; Routledge: New York, NY, USA, 2013; pp. 164-176.

92. Mwangi, E. The Transformation of Property Rights in Kenya's Maasailand: Triggers and Motivations; CGIAR Systemwide Program on Collective Action and Property Rights, International Food Policy Research Institute: Washington, DC, USA, 2005.

93. Bollig, M.; Lesorogol, C. The "new pastoral commons" of Eastern and Southern Africa. Int. J. Commons 2016, 10, 665-687. [CrossRef]

94. Ichinkhorloo, B.; Yeh, E.T. Ephemeral 'communities': Spatiality and politics in rangeland interventions in Mongolia. J. Peasant Stud. 2016, 43, 1010-1034. [CrossRef] 
95. Gargallo, E. Conservation on contested lands: The case of Namibia's communal conservancies. J. Contemp. Afr. Stud. 2015, 33, 213-231. [CrossRef]

96. Fernandez-Gimenez, M.E. Spatial and Social Boundaries and the Paradox of Pastoral Land Tenure: A Case Study from Postsocialist Mongolia. Hum. Ecol. 2002, 30, 49-78. [CrossRef]

(c) 2018 by the author. Licensee MDPI, Basel, Switzerland. This article is an open access article distributed under the terms and conditions of the Creative Commons Attribution (CC BY) license (http:/ / creativecommons.org/licenses/by/4.0/). 